\title{
JUURNAL.RU
}

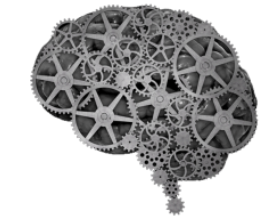

COMPANY GROUP "INTELLEKT"

\author{
Войт А.В. \\ Ульяновский государственный университет \\ Ульяновск, Россия
}

doi: 10.18411/1j2016-4-39

\section{Научно-производственные объединения: организационно-правовые аспекты интеграции}

С точки зрения правового регулирования вопросы интеграции компаний являются весьма дискуссионными. Дело в том, что в действующем законодательстве РФ единое понятие, характеризующее интеграцию хозяйствующих субъектов, пока отсутствует, что актуализирует проблематику определения правового статуса и организационно-правовых форм экономической интеграции. Усиливает актуальность вопроса терминологическое разнообразие в работах, посвященных интеграционным процессам: в одном значении нередко используются такие понятия, как «интегрированная корпоративная система», «интегрированная производственная система», «интегрированная бизнес-группа», «группа компаний» и т.п. [5]

Однако нельзя не отметить предпринимаемые в последние годы попытки исследователей упорядочить и классифицировать различные варианты интеграции. Так, согласно подходу проф. А.В. Бабкина, в качестве наиболее крупной структуры, характеризующей интеграцию участников, используется понятие «Интегрированная экономическая система». Вместе с тем, характеризуя интегрированные промышленные структуры (ИПС), как особую разновидность интегрированных экономических систем, включающую преимущественно промышленные группы и финансово-промышленные группы, созданные на основе крупных промышленных предприятий, автор обращает внимание на 
возможные юридически формы организации ИПС. [2, с.13] К таковым он относит:

- ИПС, подлежащие обязательной интеграции (акционерные общества, простые товарищества);

- ИПС, не подлежащие обязательной интеграции (финансовопромышленные группы, холдинги и холдинговые компании).

На наш взгляд, этот подход в основе своей вполне приемлем для характеристики возможных вариантов образования научно-производственных объединений (НПО). В отличие от иных форм интеграции, НПО призваны осуществлять полный цикл работ - от научных исследований до внедрения новых технических решений в производство. [6, с.826] Таким образом, НПО могут представлять из себя:

- единое юридическое лицо, и в данном случае интеграция реализуется в максимальной форме, по сути, происходит слияние компаний - участников объединения.

- объединение юридических лиц в форме холдинга или финансовопромышленной группы с добровольным делегированием участников как юридически самостоятельных организаций части управленческих функций совместно учрежденному центру. [7, c.135-137]

Нельзя не отметить, что функционирование НПО в форме холдинга сопряжено с наличием особого рода рисков. Поскольку холдинги - достаточно молодое явление в российской экономике, их правовым регуляторам деятельности в отечественном законодательстве уделено мало внимания. В настоящее время в Гражданском кодексе РФ в принципе отсутствует определение данной формы объединений. [3, с.141-151.]

Соответственно, особых механизмов управления для холдинговых образований законодательством не предусмотрено. В этой связи правовой проблемой управления в холдинге является то, что отсутствует возможность 
управлять дочерними предприятиями путем издания «приказов по холдингу»: хотя организации экономически едины, формально они сохраняют статус отдельных юридических лиц, и никакой организационно-распорядительный документ не вправе перешагнуть административные границы юридического лица [1]. Несомненно, практикой выработаны определенные механизмы решения данного вопроса: создание совета или коллегии холдинга, в которых участвуют руководители как основного, так и дочерних обществ, для принятия стратегически значимых решений; аналогичным образом создаваемые ревизионные комиссии для обеспечения корпоративного контроля и т.п.

Тем не менее, потенциальными проблемами функционирования интегрированных структур холдингового типа являются:

- перегруженность информационных потоков в отношении стратегических задач, реализуемых бизнес-процессов и т.д.;

- сложность организации процедур контроля, управленческого учета и т.п. ввиду наличия желания участников сохранить конфиденциальность информации;

- возможная диспропорция либо дублирование подразделений и направлений деятельности участников. [4]

В научно-производственных объединениях, предполагающих значительную сущностную и функциональную разнородность участников, данные проблемы могут иметь критическое значение в обеспечении эффективного развития, ведь различия в компетенциях участников НПО холдингового типа провоцируют снижение скорости и качества принимаемых специальными централизованными управленческими органами. В этой связи представляется менее рисковым создание научно-производственного объединения путем создания единого юридического лица. 


\section{Литература:}

1. Афанасьев М.В., Данилочкина Н.Г., Милованов П.Д., Ряпухин А.В. Механизм корпоративного управления в интегрированных структурах холдингового типа ракетно-космической промышленности России // Электронный журнал «Труды МАИ». Выпуск 53. [Электронный ресурс]. - Режим доступа: http://www.mai.ru/science/trudy/

2. Бабкин А.В. Теоретические основы развития экономических систем в современных условиях // Вестник АГТУ. Сер. Экономика. 2014. №4.

3. Глущенко M.Е., Нарежнева О.В. Экономико-правовые аспекты функционирования холдинговых структур // Вестник Омского университета. Серия «Экономика». 2012. №1.

4. Зезюлин В.В. Основные проблемы формирования системы управления инвестициями холдинговых образований в современных условиях // Транспортное дело России. 2008. №06.

5. Пономаренко Т.В., Пономаренко Е.И. Экономико-правовой статус корпоративных объединений // Сборник научных статей «Проблемы системной модернизации экономики России: социально-политический, финансово-экономический и экологический аспекты». СПб.: Институт бизнеса и права, 2010. [Электронный ресурс]. - Режим доступа: http://www.ibl.ru/konf/021210/45.html

6. Разумов И.А., Рожкова Е.В. Особенности современных научнопроизводственных объединений // Экономика и предпринимательство. 2015. №7.

7. Рожкова Е. В. Инновационный менеджмент: учебное пособие для студентов, обучающихся по специальности "Менеджмент организации. Ульяновск : УлГУ, 2011. 